\title{
Örgütsel Destek Algısının İşten Ayrılma Niyeti Etkisinde Personel Güçlendirmenin Aracı ve Düzenleyici Rolü:Tekstil Sektöründe Yapısal Eşitlik Modeli Uygulaması
}

DOI: 10.26466/opus.738785

\section{Emre Yakut *}

* Dr. Öğr. Üyesi, Osmaniye Korkut Ata Üniversitesi, İ.̇̇.B.F, Osmaniye/Türkiye E-Posta: emreyakut@osmaniye.edu.tr

ORCID: $\underline{0000-0002-1978-0217}$

Öz

Örgütsel destek algısı, yönetim ile çalışan arasındaki iletişime etki etmesi, yönetimin çalışana adil ve iyi davranışta bulunmasıyla iş sorumlulukların yerine getiren çalışanın iş tatmini ve örgütsel bağllĭı̆̆ın arttırmaktadır. Bireylerin iş yerinde karar verme sürecine katılmasına ve düşüncelerini özgürce ifade edebilmesine katkı sağlayan personel güçlendirme algısı, düşük seviyede ortaya çıkmasıyla çalışanların örgütsel bağglılığı ile performansının azalmasına ve işten ayrılma niyetinin artmasına neden olabilmektedir. Bu çalışmanın amacı, çalışanların örgütsel destek algısının işten ayrılma niyeti etkisinde personel güçlendirmenin aracı ve düzenleyici etkisini ortaya koymaktır. Çalışmadaki veriler tekstil sektöründeki çalışanlara uygulanan anket verisinden elde edilmiştir. Çalışma kapsamında ölçeklerin geçerlik ve güvenirlik analizleri gerçekleştirildikten sonra hipotezlerin doğruluğunu test etmek için yapısal eşitlik modeli analizi için Lisrel 8.7 yazılımı kullanılmıştır. Araştırma sonucunda elde edilen bulgular örgüt destek algısının personel güçlendirmeyi pozitif yönde etkilediği ve örgütsel destek algısının işten ayrilma niyeti etkisinde personel güçlendirmenin aracı etkiye sahip olduğu sonucunu ortaya koymuştur. Ayrıca düzenleyici etki analizinde personel güçlendirmenin yüksek, orta ve düşük düzeyleri için çalışanların örgütsel destek algıları arttıkça işten ayrılma niyetinde azalmanın gerçekleştiği tespit edilmiştir.

Anahtar Kelimeler: Örgütsel Destek Algısı, Personel Güçlendirme, İşten Ayrılma Niyeti, Yapısal Eşitlik Modeli 


\title{
Examining Medaiting and Moderating Role of Personnel Empowerment in the Effect of the Perceived Organizational Support on intention to leave work: Structural Equation Model Application in Textile Sector \\ *
}

\begin{abstract}
Perceived organizational support increases the job satisfaction and organizational commitment of the employee who fulfills their job responsibilities with the management's fair and good behavior while affecting the communication between the management and employee. The perception of employee empowerment which contributes to enabling employees to participate in decision-making processes and express themselves freely in the work place may decrease the organizational commitment and performance of employees and increase the intention to quit if it occurs in low level. This study aims to reveal the mediating and moderating role of employee empowerment in the effect of perceived organizational support on the intention to quit. The study data were obtained from the scales conducted with employees in the textile sector. After conducting the validity and reliability analyses of the scales within the scope of the study, Lisrel 8.7 software was used for the structural equality model to test the accuracy of hypotheses. The findings of the study revealed that perceived organizational support positively affected employee empowerment, and employee empowerment had an mediating role on the effect of perceived organizational support on the intention to quit. The study also found in the moderating analysis that the intention to quit decreased as perceived organizational support increased in the low, moderate and high levels of employee empowerment.
\end{abstract}

Keywords: Perceived Organizational Support, Empowerment, Intention to Quit, Structural Equation Model 


\section{Giriş}

Çalışanın örgütsel destek algısı, yönetim ile çalışan arasındaki iletişime etki etmekte (Wayne vd., 1997), yönetimin çalışana adil ve iyi davranışta bulunmasıyla iş sorumluluklarını yerine getiren çalışanın iş tatminini ve örgütsel bağlılığını arttırmaktadır (Eisenberger vd., 2001). İşten ayrılma niyetinin nedenlerinden olan örgütsel destek algisı (Rhoades ve Eisenberger (2002), bireyin işyerinde sosyo-duygusal olarak ihtiyaçlarını yerine getirirken bireyin iş tatminin artmasına ve işten ayrılma niyetinin azalmasına etki etmektedir (Knapp vd., 2017, s.656).

Bireylerin iş yerinde karar verme sürecine katılmasına ve düşüncelerini özgürce ifade edebilmesine katkı sağlayan personel güçlendirme algısı (Brymer, 1991), düşük seviyede ortaya çıkmasıyla çalışanların örgütsel bağlllığ 1 ile performansının azalmasına ve işten ayrılma niyetinin artmasına neden olabilmektedir (Kim ve Fernandez, 2017; Singh ve Singh, 2019).

Bu çalışmanın amacı tekstil sektöründeki çalışanların örgütsel destek alg1sının işten ayrılma niyeti üzerindeki etkisinde personel güçlendirmenin aracı ve düzenleyici etkisini incelemektir. Çalışanların personel güçlendirme alg1sını etkileyebilecek işyerindeki bir örgütsel destek anlayışının çalışanların işten ayrılma niyetine etki edeceği, işyerindeki işgücü devir hızı ve işgücü maliyetlerini azaltacağı, sosyal ilişkilerinin gelişmesine katkı sağlayacağı düşünülmektedir. Bu anlamda örgütsel destek anlayışı yöneticiler ve çalışanlar açısından iş hayatında önem arz etmektedir. Ayrıca, bu araştırmada çalışanların örgütsel destek algısının işten ayrılma niyeti üzerindeki etkisinde personel güçlendirmenin aracı ve düzenleyici etkisi ayrıntılı olarak incelenmeye çalışılacaktır.

Çalışma altı bölümden oluşmakta olup, birinci bölümde giriş kısmı anlatılmış, ikinci bölümde kavramlar açıklanmaya çalışılmış, üçüncü bölümde kavramlar arasındaki ilişkileri konu olan çalışmalar özetlenmiş, dördüncü bölümde çalışmanın metodolojisi kapsamında araştırmanın örneklemi, kullanılan ölçekler ve veri toplam yönteminden bahsedilmiş, beşinci bölümde araştırmanın analiz ve bulguları açıklanmaya çalışılmış ve son olarak altıncı bölümde sonuç ve öneriler yer almıştır. 


\section{Kurumsal Çerçeve}

\section{Örgütsel Destek Algısı}

Örgütsel destek algısı, örgütün çalışanların yaptıkları işlere değer vermesi ve refahlarını önemsemesine ilişkin bireylerin duyguları olarak tanımlanmaktadır (Eisenberger vd., 1986, s.500; İplik vd., 2014, s.111; Polatc1, 2015, s.26). Örgütsel destek algısı, bireylerin algıladıkları duygular olup işyerine ve örgüte karşı davranışlarını etkilemektedir (Erdoğan, 1996, s.2; Taştan vd., 2014, s.122). Başka bir ifadeyle DeConinck vd., (2015), örgütsel destek algısını sosyal mübadele kuramına dayandırırken çalışanın gerçekleştirdiği faaliyetlere karşıllk yönetim tarafından beklediği olumlu ya da olumsuz tepki olarak açıklamışlardır (Demirer, 2017, s.1046).

Örgütün gerçekleştirdiği politikaların bireyler tarafından algılanmasını ifade eden örgütsel destek teorisi, bireylerin örgüt uygulamalarının faydalı olmalarına katkı sağladığını algıladıklarında örgütsel bağlılık ve artan performansla karşıllk verebileceklerini önermektedir (Rhoades ve Eisenberger, 2002, s.698; Demircan ve Yıldız, 2009, s.75). Örgütsel destek algısı sayesinde onaylama ve saygı duyma gibi sosyo-duygusal ihtiyaçları karşılanan bireylerin artan iş performansına bağlı olarak örgütteki iş tatminleri ve örgütsel bağlılıkları artarken işten ayrılma niyetlerinde azalmanın olduğu sonuçları ortaya çıkmaktadır (Rhoades ve Eisenberger, 2002, s.700; Tanrıverdi ve Kılıç, 2016, s.6).

Bireylerin örgütsel destek algısına neden olan iletişim deneyimleri örgütsel destek algısında önem arz etmekte olup, bireylerin yönetim tarafından değerli olduklarına ilişkin olumlu mesajlar almaları örgütsel destek algısına yol açmaktadır (Yılmaz ve Görmüş, 2012, s.4492). Bununla birlikte yöneticilerin çalışanlarına adaletli olması, yönetici desteği sağlaması, bireyleri ödüllendirmesi, çalışma şartlarını kolaylaştırması ve terfi olanağını sağlaması gibi unsurlarla bireylerin örgütsel destek algisı artmakta, bu sayede bireyler örgüte daha fazla katkı sağlamaktadırlar (Akkoç vd., 2012, s.113). 


\section{Personel Güçlendirme}

Personel güçlendirme, örgütsel yapılar içinde üst yönetimin çalışanın yetki ve sorumluluk kazanmasını sağlayarak işin sahibi haline gelmesi, işi yapabilecek cesarete sahip olması, işi ile ilgili tecrübe kazanması ve özgüven düzeyinin artmasına neden olmaktadır (Gürbüz vd., 2013, s.791; Yüksel ve Adıgüzel, 2015, s.1020). Thomas ve Velthouse (1990), insan kaynakları uygulamalarından olan personel güçlendirme uygulaması çalışana güç ve yetki vererek çalışanın harekete geçmesini sağlayan bir insan kaynakları uygulamasıdır (Karavardar, 2017, s.16). Brymer (1991), örgütteki karar verme sürecine çal1şanların katılması ve yöneticiler tarafından çalışanlara takdim edilmesidir (Mete vd., 2015, s.139). Conger ve Kanungo (1988), psikolojik bir bakış aç1sıyla, personel güçlendirmeyi çalışanın bir görevi gerçekleştirmek için kendi yeteneğinin olduğuna inandığı bir ruh hali olarak açıklamıştır. Spreitzer (1995, s.1443), personel güçlendirme kavramını aşağıdaki dört kategoride s1nıflandırarak açıklamıştır (Çavuş, 2008; Kitapci vd., 2013, s.52; Mete vd., 2015, s.139; Yılmaz ve Karahan, 2015, s.613; Karavardar, 2017, s.16; Eskibina, 2019, s.1607):

Anlam kavramı: Personelin sorumluluğunu üstlendiği göreve ilişkin algıladığı anlam ile kendi hedeflerinin birbirleriyle uyumlu olup olmamasıdır. Thomas ve Velthouse (1990), Düşük seviyedeki anlamlılık çalışan üzerinde ilgisizlik ve kayıtsızlık olarak ortaya çıkarken, yüksek seviyedeki anlamlılık tam tersine işe olan bağlllığa ve sahiplenmeye neden olmaktadır (Karavardar, 2017, s.17).

Yetkinlik kavramı: Spreitzer (1995), personelin verilen işi yapabileceğine inandığı yeteneklerin kendisinde olduğunu ifade etmektedir (Mete vd., 2015, s.139). Düşük seviyedeki yetkinlik, personelin güven eksikliğine neden olurken çalışan sorumluluk almaktan kaçınarak iş tatmininin azalmasına etki edecektir (Thomas ve Velthouse, 1990).

Özerklik kavramı: Gagne ve Deci (2005), özerklik kavramını personelin işi ile ilgili kendi başına karar verebilmesi ve bağımsız olarak seçim yapabilmesi olarak açıklamışlardır (Kitapcı vd., 2013, s.53). Başka bir ifadeyle, Spreitzer 
vd., (1999), özerkliği personelin işi ile ilgili konularda özgürce kararlar alabilmesi olarak tanımlamışlardır.

Etki kavramı: Örgütsel katılımı ifade eden etki kavramı, personelin çalışma hayatındaki koşullara stratejik açıdan ve yönetimsel anlamda kendisini göstermesidir (Spreitzer vd., 1997).

\section{İşten Ayrulma Niyeti}

Bireyin iş yerinde çalışmama isteğini ifade eden işten ayrılma niyeti (Porter vd., 1974), belirli bir süreç içerisinde bireyin çalıştığ iş yerinden gönüllü ya da gönülsüz olarak ayrılmasına neden olurken (Mobley, 1982), bunu birey planlı ve bilinci olarak arzulamaktadır (Tett ve Meyer, 1993, Bayarçelik ve Fındıklı, 2017:19; Bayarçelik, 2020:38). İşyerinden ayrılmayı isteyen çalışan nitelikli ve işletmenin önemli bir personeli ise bu durum işletme için kayıp olurken, niteliksiz ve işletmenin verimsiz bir personeli ise işletme için bu durumda kayıp olarak düşünülmeyecektir (Arı vd., 2010, s.146).

Çalışanın iş koşullarından dolayı memnuniyetsizliğinin artmasına bağlı olarak işyerinden ayrılma eğiliminde olması işletme için işgücü devir hızını artırabileceği gibi işgücü maliyetlerinin de artmasına neden olabilecektir (Beğenirbaş ve Çalışkan, 2014, s.114; Kanbur, 2018, s.150). Bununla birlikte işletmeler işten ayrılma niyetini önleyici tedbirler almadığı takdirde bu durum zamanla diğer çalışanları da etkileyerek işyerinde işgücü kaybına yol açabilecektir (Onay ve Kılcı, 2011, s.365). Ayrıca işten ayrılma niyeti çalışanlar arasındaki sosyal ilişkileri zayıflatırken örgütleri ve çalışanları olumsuz etkilemesi nedeniyle işletmeler için önem arz etmektedir (Yürür ve Ünlü, 2011, s.159; Yılmaz ve Eroğluer, 2018, s.68).

Çalışanın iş tatmininin azalması, örgütsel bağlılığını yitirmesi, iş ve ailesi arasındaki çatışma durumunun ortaya çıkması, duygusal tükenmişliği, sağlık problemleri, iş yerindeki sosyal ilişkilerinin yetersizliği ve sosyal çevre faktörünün kendisi üzerindeki etkisi gibi faktörler çalışanın işten ayrılma niyetine etki etmektedir (Kaymaz vd., 2014, s.45). 


\section{Literatür İncelemesi}

\section{Örgütsel Destek Algısı ile İşten Ayrılma Niyeti Arasındaki İlişki}

Örgütsel destek algısı ile işten ayrılma niyeti arasındaki ilişkilerin incelendiği çalışmalar aşağıda özetlenmiştir.

Foong-ming (2008), Malezya'da bilişim sektöründeki çalışanlara gerçekleştirdikleri uygulamada kariyer geliştirme uygulamalarının işten ayrılma niyetine etkisinde örgütsel destek algısının aracı etkisini analiz ederek çalışanların örgütsel destek algısı ile işten ayrılma niyeti arasında negatif bir ilişkinin olduğunu ortaya koymuştur.

Filipova (2011), ABD'de hemşirelere uyguladıkları çalışmada örgütsel destek algisının işten ayrılma niyeti üzerindeki etkisinde iş tatmini ve örgütsel bağlılığın aracı etkisini araştırarak hemşirelerin örgütsel destek algısının işten ayrılma niyetine yönelik dolaylı etkisinin azaltıc yönde olduğunu tespit etmiştir.

Duarte vd., (2015), Portekiz'de otel çalışanlarına uyguladıkları çalışmada İK uygulamasının işten ayrılma niyeti etkisinde örgütsel destek algısının aracı etkisinin olduğunu tespit etmiş ve işten ayrılma niyeti ile negatif ilişkiye sahip olduğunu açıklamışlardır.

Kumar (2015), Hindistan'da bilişim teknolojileri sektöründeki çalışanlara uyguladıkları araştırmada örgütsel destek algısı ile örgütsel adalet algısının işten ayrılma niyeti üzerindeki etkisinde çalışan bağlılığının aracı etkisini inceleyerek çalışanların örgütsel destek algısının dolaylı ve dolaysız etkisinin işten ayrılma niyeti üzerinde azaltıcı yönde olduğunu belirtmiştir.

Liu ve Liu (2015), Çin'de hemşirelere uyguladıkları çalışmada örgütsel destek algısının işte kalma niyeti üzerindeki etkisinde kariyer başarısının aracı etkisi ile öz saygının düzenleyici etkisini inceleyerek hemşirelerin örgütsel destek algısının işte kalma niyetini pozitif yönde etkilediği sonucunu ortaya koymuşlardır.

Saoula ve Johari (2016), Malezya'da bilişim ve iletişim sektöründeki çalışanlara gerçekleştirdikleri uygulamada örgütsel destek algısının işten ayrılma niyetine yönelik etkisinde örgütsel vatandaşlık davranışını aracı etkisini inceleyerek her iki değişkenin işten ayrılma niyetinde azaltıcı etkisinin olduğunu belirtmişlerdir. 
DeConinck ve DeConinck (2017), ABD'de satış temsilcilerine gerçekleştirdikleri çalışmada hizmetkâr liderlik anlayışının işten ayrılma niyeti üzerindeki etkisinde örgütsel destek algısı ve çalışan performansının aracı etkisini inceleyerek çalışanların örgütsel destek algısının işten ayrılma niyetine yönelik dolaylı ve dolaysız etkisinin negatif yönde olduğu sonucunu ortaya koymuştur.

Yukarıda bahsedilen çalışmalardan hareketle örgütsel destek algısı ile işten ayrılma niyetine ilişkin geliştirilen hipotez şu şekildedir:

- H1: Örgütsel destek algısı ile işten ayrılma niyeti arasında negatif yönlü bir ilişki bulunmaktadır.

\section{Personel Güçlendirme ile İşten Ayrılma Niyeti Arasındaki İlişki}

Personel güçlendirme ile işten ayrılma niyeti arasındaki ilişkilerin ele alındığı çalışmalar aşağıda özetlenmeye çalışılmıştır.

Bhatnagar (2012), Hindistan'da ilaç sektöründe görev yapan yöneticilere uyguladıkları çalışmada personel güçlendirmenin işten ayrılma niyetine yönelik etkisinde işe tutkunluk değişkeninin aracı etkisini inceleyerek yöneticilerin personel güçlendirme algısının işten ayrılma niyetine yönelik dolaylı etkisinin azaltıcı yönde etkili olduğunu açıklamıştır.

Lim vd., (2016), Malezya'da banka çalışanlarına uyguladıkları çalışmada personel güçlendirme, örgütsel destek algısı ve iş tatmininin işten ayrılma niyeti üzerindeki etkisini inceleyerek çalışanların personel güçlendirme algısı ile işten ayrılma niyeti arasındaki ilişkinin negatif yönlü olduğunu belirtmişlerdir.

Kim ve Fernandez (2017), ABD'de federal hükümetin ve bağımsız ajansın çalışanlarına gerçekleştirdikleri uygulamada personel güçlendirmenin işten ayrılma niyetine yönelik etkisinde iş tatmininin aracı etkisini analiz ederek çalışanların personel güçlendirme algısının işten ayrılma niyetine yönelik dolaylı etkisinin azaltıcı yönde olduğunu ortaya koymuşlardır.

Hampton ve Rayens (2019), ABD'de hemşirelere uyguladıkları araştırmayla personel güçlendirme ile işyerindeki mobbing ve personel güçlendirme ile işten ayrılma niyeti arasında negatif yönlü bir ilişkinin bulunduğunu ortaya koymuşlardır. 
Lyu vd., (2019), Çin'de hemşirelere uyguladıkları çalışmada istismarcı yönetim anlayışının işten ayrılma niyeti üzerindeki etkisinde personel güçlendirmenin aracı etkisini araştırarak hemşirelerin personel güçlendirme alg1S1 ile işten ayrılma niyeti arasında negatif yönlü bir ilişkinin tespit edildiğini vurgulamışlardır.

Yukarıda açılanan araştırmalar sonucunda personel güçlendirme ile işten ayrılma niyetine yönelik geliştirilen hipotez şu şekildedir:

- $\mathbf{H}_{2}$ : Personel güçlendirme ile işten ayrılma niyeti arasında negatif yönlü bir ilişki bulunmaktadır.

\section{Personel Güçlendirmenin Aracı ve Düzenleyici Rolü}

İşyerindeki çalışanın saygı görmesi ve mutluluğunun derecesini gösteren örgütsel destek algısının işten ayrılma niyetine yönelik etkisinde personel güçlendirmenin aracı etkisinin araştırıldığı literatürde sınırlı sayıda çalışma yapılmışken, düzenleyici etkisine rastlanılamamıştır. Bu çalışmada personel güçlendirmenin düzenleyici etkisinin de incelenmesi ilgi çekici olacaktır.

Benzer ifadeyle, Iqbal ve Hashmi (2015), Pakistan'da yüksek öğretimde görev yapan çalışanlara uyguladıkları araştırmada çalışanların örgütsel destek algısının işten ayrılma niyetine yönelik etkisinde personel güçlendirmenin aracı etkisini inceleyerek örgütsel destek algısının işten ayrılma niyetine yönelik dolaylı ve personel güçlendirmenin işten ayrılma niyeti üzerindeki doğrudan etkisinin azaltıcı yönde etkili olduğunu ortaya koymuşlardır.

Akgündüz ve Bardakoğlu (2017), Türkiye' de otel çalışanlarına gerçekleştirdikleri uygulamada örgütsel özdeşleşme ve örgütsel destek algısının işten ayrılma niyeti üzerindeki etkisinde personel güçlendirmenin aracı etkisini analiz ederek işten ayrılma niyeti üzerinde örgütsel destek algısının dolaylı ve personel güçlendirmenin doğrudan etkisinin negatif yönlü olduğu sonucuna ulaşmışlardır.

Benzer şekilde, Manzoor vd., (2016), Çin'de üniversite çalışanlarına gerçekleştirdikleri uygulamada insan kaynakları uygulamaları ile çalışanların iş performansı arasındaki ilişkide personel güçlendirmenin düzenleyici etkisini analiz ederek insan kaynakları uygulamaları ile personel güçlendirme etkileşiminden oluşan etkileşim değişiminin iş performansı üzerinde pozitif yönlü etkiye sahip olduğunu saptamışlardır. 
Farzaneh vd., (2014), İran'da gaz dağıtım şirketinin çalışanlarına gerçekleştirdikleri uygulamada kişi organizasyon uyumu ile örgütsel vatandaşlık davranışı arasındaki ilişkide personel güçlendirmenin düzenleyici etkisini inceleyerek kişi organizasyon uyumu ile personel güçlendirmenin etkileşimden oluşan etkileşim değişkeninin örgütsel vatandaşlık davranışı üzerinde pozitif yönde etkisinin olduğu sonucuna ulaşmışlardır.

Yukarıda bahsedilen araştırmalar sonucunda personel güçlendirmenin aracı ve düzenleyici rolüne ilişkin geliştirilen hipotezler şu şekildedir:

- $\quad \mathbf{H}_{3}$ : Örgütsel destek algısının işten ayrılma niyetine etkisinde personel güçlendirmenin aracı rolü bulunmaktadır.

- $\quad H_{4}$ : Örgütsel destek algısı ile işten ayrılma niyeti ilişkisinde personel güçlendirmenin düzenleyici rolü bulunmaktadır.

Bu çalışmada örgütsel destek algısının işten ayrılma niyeti üzerindeki etkisinde personel güçlendirmenin aracı ve düzenleyici etkisinin olup olmadığ incelenecektir. Yapılan literatür taraması sonucunda ileri sürülen hipotezlere ilişkin olarak aşağıda araştırmanın modeli Şekil 1'de gösterilmiştir.

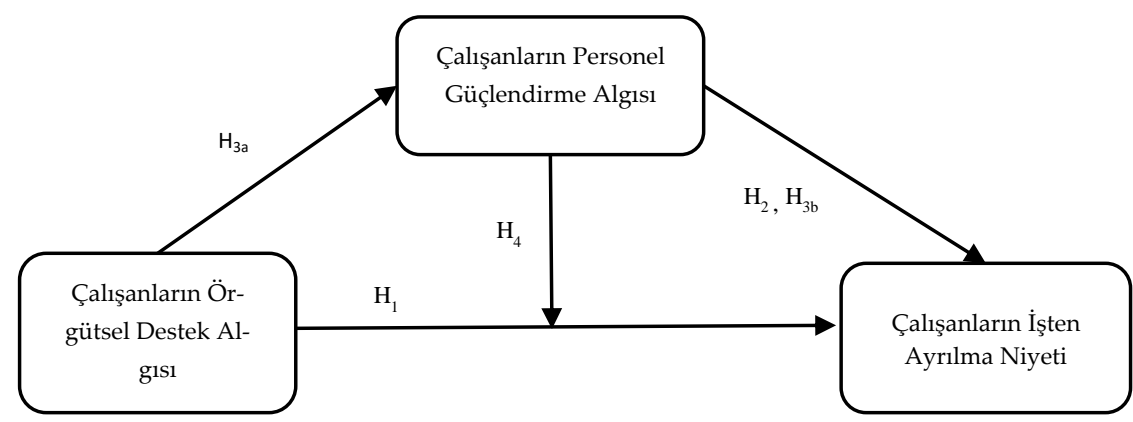

Şekil 1. Araştırma Modeli

\section{Metodoloji}

Yapılan literatür taraması sonucunda oluşturulan modelin test edilmesine yönelik kovaryans tabanlı çalışan Lisrel 8.7 paket programı kullanılmış, yapısal eşitlik modeli ile aracı değişken analizi gerçekleştirilmiş, ardından SPSS Process macrosundan yararlanılarak düzenleyici değişken analizi yapılmıştir. 


\section{Araştırmanın Örneklemi}

Çalışanların örgütsel destek algısının işten ayrılma niyeti üzerindeki etkisinde personel güçlendirmenin aracı ve düzenleyici rolünün belirlenmesi amaçlanmış, bu araştırmada kullanılacak veriler kolayda örnekleme yöntemi ile Gaziantep'te Tekstil Sektöründe faaliyet gösteren firmaların çalışanlarına online olarak hazırlanan anket formu iletilerek veriler toplanmıştır. Anketi dolduranlar arasından ancak 264 çalışanın anket verileri kullanılmak üzere hazır hale getirilmiştir. Tablo 1'de ankete katılan tekstil sektörü çalışanlarının demografik bilgileri yer almaktadır.

Tablo 1. Çalışanların Demografik Özelliklerine İlişkin Veriler

\begin{tabular}{|c|c|c|c|c|c|}
\hline Kategorik Değişkenler & $\mathbf{N}$ & $\%$ & Kategorik Değişkenler & $\mathbf{N}$ & $\%$ \\
\hline Cinsiyeti & & & Medeni Durum & & \\
\hline Kadın & 111 & 42 & Evli & 142 & 53,9 \\
\hline Erkek & 153 & 58 & Bekar & 122 & 46,1 \\
\hline \multicolumn{6}{|l|}{ Eğitim Seviyesi } \\
\hline Lise & 30 & 11,4 & İşletmedeki Hizmet Süresi & & \\
\hline Önlisans & 51 & 19,3 & 1 yıldan az & 18 & 6,8 \\
\hline Lisans & 175 & 66,3 & $1-4$ yil & 101 & 38,3 \\
\hline Lisansüstü & 8 & 3 & $5-8$ yil & 64 & 24,3 \\
\hline İşletmedeki Pozisyonu & & & $9-12$ yil & 40 & 15,2 \\
\hline Personel & 99 & 37,5 & $13-16$ yil & 20 & 7,5 \\
\hline Şef & 68 & 25,8 & $17-20$ yil & 13 & 4,9 \\
\hline Orta kademe yöneticisi & 89 & 33,7 & 21 yıl ve üzeri & 8 & 3,0 \\
\hline Üst kademe yöneticisi & 8 & 3 & İş Hayatındaki Hizmet Süresi & & \\
\hline Yaş & & & 1 yildan az & 3 & 1,1 \\
\hline 19-25 & 14 & 5,3 & $1-4$ yil & 30 & 11,4 \\
\hline $26-32$ & 73 & 27,7 & $5-8$ yil & 70 & 26,5 \\
\hline 33-39 & 89 & 33,7 & 9-12 y1l & 73 & 27,7 \\
\hline $40-45$ & 50 & 18,9 & $13-16$ yil & 46 & 17,4 \\
\hline $46-52$ & 27 & 10,2 & $17-20$ yil & 23 & 8,7 \\
\hline $53-59$ & 6 & 2,3 & 21 yıl ve üzeri & 19 & 7,2 \\
\hline 60 ve üzeri & 5 & 1,9 & & & \\
\hline
\end{tabular}

Araştırmada anketi dolduran çalışanların, $\% 42$ 'sinin kadın ve $\% 58$ 'inin erkek; \%53,9'unun evli ve \%46,1'inin bekar olduğu görülmüştür. Eğitim seviyesine yönelik demografik değişkenler açısından çalışanların \%11,4'ünün lise, \%19,3'ünün ön lisans, \%66,3'ünün lisans ve \%3'ünün lisansüstü mezunu olduklarını açklamışlardır. Ankete katılanların işletmedeki mevkisi itibari ile 
$\% 37,5^{\prime}$ inin personel pozisyonunda, $\% 25,8^{\prime}$ sinin şef pozisyonunda, $\% 33,7^{\prime}$ sinin orta kademe yöneticisi pozisyonunda ve \%3'ünün üst kademe yöneticisi pozisyonunda olduklarını belirtmişlerdir. Yaş kategorik değişkeni bakımından anketi dolduranların \%33'ünün 19-32 yaş aralığında, \%52,6'sının 33-45 yaş aralığında, \%14,4'ünün 46 ve üstü yaş aralığında oldukları anlaşılmıştır. Ankete cevap verenlerin \%45,1'i 4 yıldan az, \%24,3'ü 5-8 yll arasinda ve $\% 15,2$ 'si 9-12 yıl arasında ve \%15,4'ünün 13 yıl ve üzeri çalıştığ met süresine sahip olduğunu ifade etmişlerdir. Ankete katılanların \%12,5'inin 4 yıldan az, \%26,5'inin 5-8 yıl arasında ve \%27,7'sinin 9-12 yıl arasında ve \%33,3'ünün 13 yıldan fazla iş yaşamlarında hizmet süresine sahip olduklarını belirtmişlerdir.

\section{Araştırmada Kullanılan Ölçüm Araçları}

Örgütsel destek algısı: Araştırmada bireylerin örgütsel destek algısını ölçmek için Eisenberger vd., (1986) tarafından geliştirilmiş 8 maddelik ve tek boyutlu ölçek kullanılarak gerçekleştirilmiştir (Naktiyok ve Kızıl, 2018, s.273).

Personel güçlendirme algısı: Çalışanların personel güçlendirme algılamalarını ölçmek için Spreitzer (1995) tarafından geliştirilmiş 12 maddelik ve dört boyuttan oluşan ölçek kullanılmıştır (Çavuş, 2008:1292; Candan, vd., 2016, s.257).

İşten ayrılma niyeti algısı : Çalışanlara yönelik işten ayrılma niyetini ölçmede Cammann (1983) tarafından geliştirilmiş olan 3 maddeli ölçek uygulanmıştır (Gürbüz ve Pekmezci, 2012, s.198).

Anket formunun uygulanmasinda Osmaniye Korkut Ata Üniversitesi Bilimsel Araştırma ve Yayın Etiği Yönergesi hükümlerince Osmaniye Korkut Ata Üniversitesi Bilimsel Araştırma ve Yayın Etiği Kurulu'na başvuru yapılarak kurul tarafından uygun görülen Etik Kurul Onay Belgesi alınmıştır.

\section{Verilerin Analizi}

Çalışmada verilerin analizinde aracı değişken analizi için Lisrel 8.7 yazılımından yararlanılarak kovaryans temelli yapısal eşitlik modeli analizi gerçekleş- 
tirilmiş, düzenleyici değişken analizi için Hayes'in SPSS Process makrosundan yararlanılarak modellerin geçerliliği ve hipotezleri test edilerek doğruluğu saptanmıştır.

Ölçeklerin Geçerlilik ve Güvenilirlik Analizleri: Araştırmanın hipotezlerini doğrulamak için yapısal eşitlik modeli analizine geçmeden önce ölçeklerin yapısal geçerliliği için doğrulayıcı ve açıklayıcı faktör analizi uygulanmıştır. Çalışma kapsamında ilk önce kullanılan ölçekler için faktör yapılarını belirlemek amacıyla açıklayıcı faktör analizi uygulanmıştır. Açıklayıcı faktör analizinden önce veri setinin faktör analizine uygunluğunu test etmek için KMO testi gerçekleştirilmiş ve bu değer 0,862 olarak hesaplanarak örneklem uyumunun iyi düzeyde olduğu belirlenmiştir (Çokluk vd., 2010, s.207; İplik, 2019:937). Bununla birlikte veri setinin çoklu normal dağılıma sahip olup olmadığını belirlemek için Bartlett küresellik testi analizi uygulanmış ve bu değerin $\left(\chi^{2}=4779, p<0,000\right)$ sonucunun anlamlı olduğu görülmüştür.

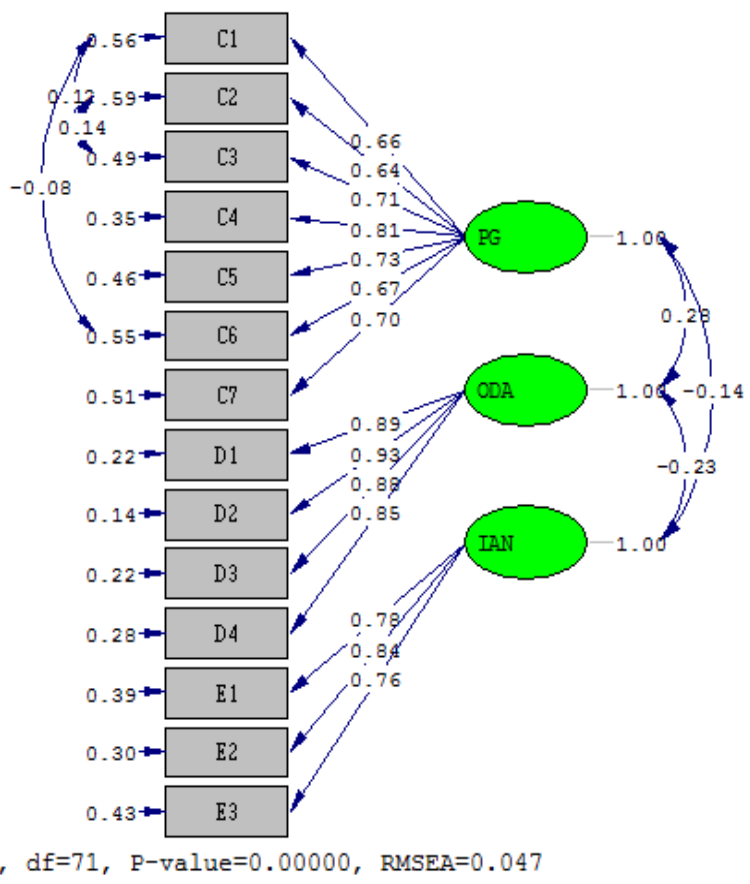

Şekil 2. Araştırma modeline ait doğrulayıcı faktör analizi 
Açiklayıcı faktör analizinde yöntem olarak temel bileşenler analiz yöntemi seçilip varimax metodu ile döndürme işlemi gerçekleştirilerek 3 faktörlü yapı elde edilmiş ve personel güçlendirme faktörü için $\% 28,83$, örgütsel destek algisı faktörü için \%23,93 ve işten ayrılma niyeti için \%16,32'lik toplamda ise \%69,08'lik varyansı açıklama oranı tespit edilmiştir. Her üç faktörün özdeğeri de kritik değerin üzerinde gerçekleşmiştir.

Açılayıcı faktör analizi uygulaması sonucunda tespit edilen üç faktörün maddelerce ölçülmesi için doğrulayıcı faktör analizi yapılmış ve şekil 2'de araştırma modeline ilişkin doğrulayıcı faktör analizi verilmiştir.

Doğrulayıc faktör analizi uygulaması sonucunda araştırma modelinin standardize edilmiş regresyon katsayıları hesaplanarak test istatistikleri incelenmiştir. Tablo 2'de araştırmanın doğrulayıcı faktör analizine ilişkin uyum iyiliği değerleri verilmiştir.

Tablo 2. Araştırmanın doğrulayıcı faktör analizine ilişkin uyum iyiliği değerleri

\begin{tabular}{llccl}
\hline $\begin{array}{l}\text { Index } \\
\text { Değerleri }\end{array}$ & $\begin{array}{l}\text { Ölç̧egin Gösterge } \\
\text { Değerleri }\end{array}$ & $\begin{array}{l}\text { İyi Uyum } \\
\text { Değerleri }\end{array}$ & $\begin{array}{c}\text { Kabul Edilebilir } \\
\text { Uyum Değerleri }\end{array}$ & $\begin{array}{l}\text { Uyum } \\
\text { Durumu }\end{array}$ \\
\hline \multicolumn{1}{c}{$\boldsymbol{s} \boldsymbol{d}$} & 2,35 & $\leq 2$ & $\leq 3$ & Kabul edilebilir uyum \\
\hline RMSEA indeksi & 0,047 & $\leq 0,05$ & $\leq 0,08$ & İyi uyum göstermekte \\
\hline CFI indeksi & 0,98 & $\geq 0,97$ & $\geq 0,95$ & İyi uyum göstermekte \\
\hline GFI indeksi & 0,97 & $\geq 0,95$ & $\geq 0,90$ & Iyi uyum göstermekte \\
\hline
\end{tabular}

Kaynak: Tabachnik ve Fidell, 2015; Aksu vd., 2017; Alpar, 2013.

Doğrulayıc faktör analizine ilişkin modelin uyum iyiliği değerlerinin ölçüm modeliyle ilişkilendirildiğinde, ölçüm modelinin iyi düzeyde uyum sağladığ1 sonucuna ulaşılmıştır $\left(\chi^{2} / s d=2,35 ; p<0,000 ; C F I=0,98 ; G F I=\right.$ 0,97; RMSEA = 0,047). Tablo 3'te analizde kullanılan değişkenlerin Cronbach Alfa katsayıları ile korelasyon katsayıları verilmiştir.

Tablo 3. Analizde Kullanılan değişkenlere ait CA ve Korelasyon Katsayılan

\begin{tabular}{|c|c|c|c|c|c|c|}
\hline & $\overline{\boldsymbol{X}}$ & std sap. & CA & ODA & PG & IAN \\
\hline ODA & 4,25 & 0,52 & 0,934 & 1 & $0,691^{* * *}$ & $-0,226^{* * *}$ \\
\hline PG & 4,4 & 0,52 & 0,875 & $0,691^{* * * *}$ & 1 & $-0,141^{* * *}$ \\
\hline IAN & 1,83 & 0,73 & 0,833 & $-0,226^{* * *}$ & $-0,141^{* * *}$ & 1 \\
\hline
\end{tabular}


Araştırmada gizli değişkenleri ölçmek için kullanılan maddelerin birbirleriyle tutarlılığını göstermek için Cronbach Alfa katsayısı hesaplanmış, hesaplanan bu katsayıların değerleri 0,70 'in üzerinde olduğu için ölçeklerdeki maddelerin birbirleriyle tutarlı olduğu sonucuna varılmıştır. Ayrıca değişkenler arasındaki ilişkileri tespit etmek amaciyla Pearson korelasyon analizi gerçekleştirilmiş, çalışanların örgütsel destek algısı ile işten ayrılma niyeti ilişkisinde $(r=-0,226, p<0,001)$, personel güçlendirme düzeyi ile işten ayrılma niyeti ilişkisinde $(r=-0,141, p<0,001)$ istatistiksel açıdan anlamlı ve negatif yönlü bir ilişkinin olduğu belirlenmiştir. Benzer şekilde ankete katılanların örgütsel destek algısı ile personel güçlendirme ilişkisinde $(r=$ $0,691, p<0,001$ ) pozitif yönlü bir doğrusal ilişinin olduğu saptanmıştır.

\section{Yapısal Eşitlik Modeli Analizi Sonucunda Elde Edilen Bulgular}

Araştırmanın açıklayıcı ve doğrulayıc faktör analizi gerçekleştirildikten sonra yapısal eşitlik modeli ile araştırmanın hipotezleri test edilmiş, ayrıca araştırmada kovaryans temelli yapısal eşitlik modeli için en yüksek olabilirlik yöntemi seçilerek analiz işlemi gerçekleştirilmiştir.

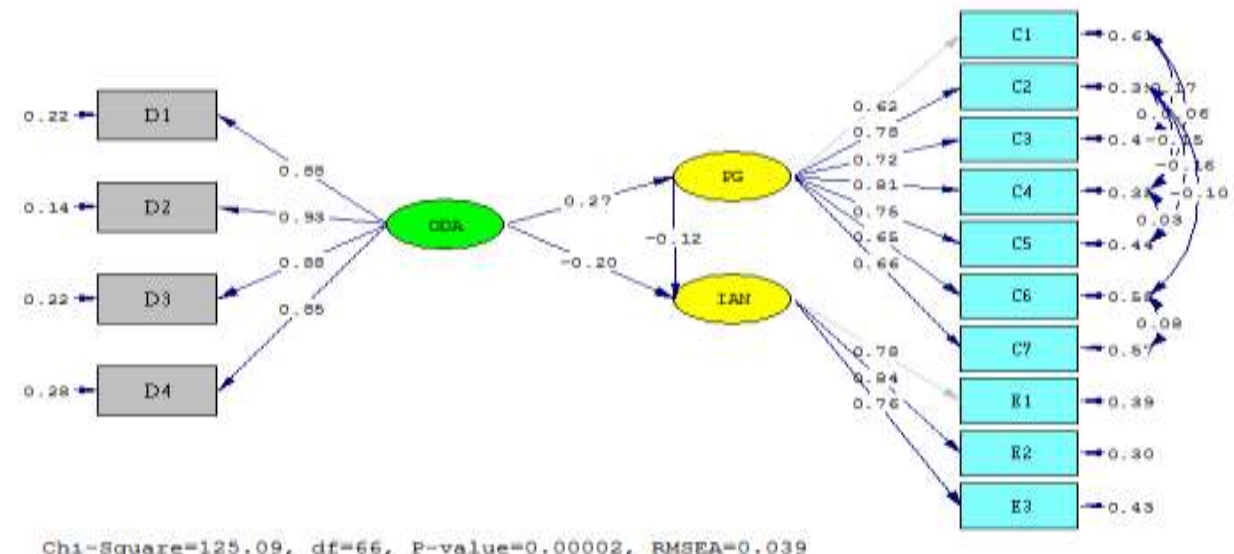

Şekil 3. Araştırmanın yapısal modeli ve standardize edilmiş katsayılan

Şekil 3'te verilen araştırmanın modeli uyum iyiliği değerleri bakımından karşılaştırıldığında $\left(\frac{\chi^{2}}{s d}=1,90 ; p<0,000 ; C F I=0,99 ; G F I 0,97 ; R M S E A=\right.$ $0,039)$ modelin iyi uyum değerlerine sahip olduğu anlaşılmıştır (Tabachnik 
ve Fidell, 2015; Aksu vd., 2017; Alpar, 2013). Şekil 3'teki standardize edilmiş regresyon katsayılarına göre çalışanların örgütsel destek $\left(\beta=-0,20 ; t_{h}=\right.$ $-4,24 ; p<0,000)$ ve personel güçlendirme algisının $\left(\beta=-0,12 ; t_{h}=\right.$ $-2,54 ; p<0,05)$ işten ayrılma niyeti üzerinde negatif yönlü etkisinin olduğu tespit edilmiş ve böylece $\mathrm{H}_{1}$ ile $\mathrm{H}_{2}$ hipotezlerinin desteklendiği anlaşılmıştır.

\section{Personel Güçlendirmenin Aracı Etki Analizi}

Araştırma modelinde aracı etkiden söz edebilmek için bağımsız değişken ile bağımlı değişken arasında, bağımsız değişken ile aracı değişken arasında ve aracı değişken ile bağımlı değişken arasındaki ilişkilerin anlamlı olması gerekmektedir (Baron ve Kenny, 1986, s.1176). Böylece Tablo 4'te araştırma modelinin doğrudan ve dolaylı etkileri gösterilmiştir.

Tablo 4. Aracı Etkiden Sonra Modelin Yol Katsayılarn

\begin{tabular}{llllll}
\hline & Etki & $\begin{array}{l}\text { Standardize } \\
\beta \text { Katsayıs }\end{array}$ & $\begin{array}{l}\text { Standart } \\
\text { Sapma }\end{array}$ & t değeri & P değeri \\
\hline $\begin{array}{l}\text { Doğru- } \\
\text { dan Etki }\end{array}$ & ODA -> IAN & $-0,20$ & 0.047 & $-4,24$ & $0.000^{* * *}$ \\
\hline $\begin{array}{l}\text { Dolaylı } \\
\text { Etki }\end{array}$ & ODA - PG - AN & $-0,032$ & 0.01 & $-3,20$ & $0.01^{*}$ \\
\hline $\begin{array}{l}\text { Toplam } \\
\text { Etki }\end{array}$ & ODA -> IAN & $-0,232$ & 0,045 & $-5,15$ & $0.000^{* * *}$ \\
\hline
\end{tabular}

${ }^{*} p<0,05,{ }^{* *} p<0,01,{ }^{* * *} p<0,001$

Araştırmada örgütsel destek algısının işten ayrılma niyeti üzerindeki doğrudan etkisi $\left(\boldsymbol{\beta}=-\mathbf{0 , 2 0} ; \boldsymbol{t}_{\boldsymbol{h}}=-\mathbf{4}, \mathbf{2 4} ; \boldsymbol{p}<\mathbf{0 , 0 0 0}\right)$, dolaylı etkisi $(\boldsymbol{\beta}=$ $\left.-0,032 ; \boldsymbol{t}_{\boldsymbol{h}}=-\mathbf{3}, \mathbf{2 0} ; \boldsymbol{p}<\mathbf{0 , 0 1}\right)$ ve toplam etkisi $\left(\boldsymbol{\beta}=-\mathbf{0 , 2 3 2} \boldsymbol{t}_{\boldsymbol{h}}=\right.$ $-\mathbf{5}, \mathbf{1 5} ; \boldsymbol{p}<\mathbf{0 , 0 0 0}$ ) istatistiksel açıdan anlamlı olduğu belirlenmiştir. Böylece personel güçlendirmenin aracı etkisinin olduğuna yönelik $\mathrm{H}_{3}$ hipotezi desteklenmektedir.

\section{Personel Güçlendirmenin Düzenleyici Etki Analizi}

Bağımlı ve bağımsız değişkenler arasındaki ilişkinin yönünü ve derecesini etkileyebilen değişken olan düzenleyici değişkeni, iki değişken arasındaki ilişkinin artmasında, azalmasında veya yön değiştirmesinde modelin açılama gücüne katkı sağlayarak anlamlı bir etkiye neden olmaktadır (Baron ve 
Kenny, 1986, s.1174). Düzenleyici değişken analizinde bağımsız değişken ile düzenleyici değişken arasında çoklu doğrusal bağlantının yaşanmaması için değişkenler standartlaştırılıp bu değişkenlerin çarpılmasının ardından elde edilen etkileşimsel etki değişkeninin bağımlı değişken üzerindeki etkisinin istatistiksel açıdan anlamlı olması gerekmektedir (Baron ve Kenny, 1986; Frazier vd., 2014, s.118). Böylece Tablo 5'te araştırma modelinin düzenleyici etki analizi sonucunda değişkenlerin etki değerleri yer almaktadır.

Tablo 5. Personel Güçlendirmenin Düzenleyici Rolü

\begin{tabular}{llllllll}
\hline \multirow{2}{*}{ Etkiler } & Ilişkinin Yönü & $\begin{array}{c}\boldsymbol{\beta} \\
\text { katsayısı }\end{array}$ & $\begin{array}{l}\text { Standart } \\
\text { sapma }\end{array}$ & thdeğeri & $\begin{array}{l}\text { Anl. } \\
\text { seviyesi }\end{array}$ & LLCI & ULCI \\
\hline \multirow{2}{*}{ Temel etki } & ODA $\rightarrow$ IAN & $-0,413$ & 0,076 & $-5,44$ & $0,000^{* * *}$ & $-0,562$ & $-0,264$ \\
\cline { 2 - 8 } & PG $\rightarrow$ IAN & $-0,142$ & 0,071 & $-2,01$ & $0,05^{*}$ & $-0,282$ & $-0,003$ \\
\hline $\begin{array}{l}\text { Etkileşimli } \\
\text { etki }\end{array}$ & ODA $\times$ PG $\rightarrow$ IAN & $-0,223$ & 0,044 & $-5,03$ & $0,000^{* * *}$ & $-0,310$ & $-0,136$ \\
\hline & R katsayıs1 & $R^{2}$ değeri & F değeri & sd1 & sd2 & $\begin{array}{l}\text { Anl. } \\
\text { seviyesi }\end{array}$ \\
\hline & 0,30 & 0,09 & 25,27 & 1 & 260 & $0,000^{* * * *}$
\end{tabular}

$p<0.05^{*}, p<0.01^{* *}, p<0.001^{* * *}$

Düzenleyici etki analizi için SPSS'in Process makrosundan yararlanılarak boostrap tekniği ile 5000 örneklem seçimi gerçekleştirilmiştir. Tablo 5 'ten elde edilen bulgular sonucunda örgütsel destek algısı ile personel güçlendirme çarpımından oluşan etkileşim değişkeninin işten ayrılma niyeti üzerinde negatif yönlü etkisinin olduğuna yönelik $\mathrm{H}_{4}$ hipotezi desteklenmiştir ( $\beta=$ $-0,223 ; p<0,000 ; \% 95 L C I=[-0,310 ;-0,136])$. Örgütsel destek algisı $(\beta=-0,413 ; p<0,000 ; \% 95 L C I=[-0,562 ;-0,264]$ ve personel güçlendirmenin $\beta=-0,142 ; p<0,05 ; \% 95 L C I=[-0,282 ;-0,003]$ işten ayrılma niyeti üzerindeki etkisinin negatif yönde anlamlı olduğu tespit edilmiştir. Ayrıca tüm modelin etkisinin anlamlı $(F=25,27 ; p=0,000)$ olduğu ve işten ayrılma niyetindeki değişkenliğin $R^{2}=\% 9^{\prime}$ luk kısmının açılandığı tespit edilmiştir. Personel güçlendirmenin farklı düzeyleri için örgütsel destek alg1sının etkileri Tablo 6'da ayrıntılı verilmiştir. 
Tablo 6. Farklı Personel Güçlendirme Düzeyleri için Örgütsel Destek Algısının Isşten Ayrilmaya Etkisi

\begin{tabular}{lllllll}
\hline $\begin{array}{l}\text { PG } \\
\text { düzeyleri }\end{array}$ & $\boldsymbol{\beta}$ katsayısı & $\begin{array}{l}\text { Standart } \\
\text { sapma }\end{array}$ & th değeri & $\begin{array}{l}\text { Anl. } \\
\text { seviyesi }\end{array}$ & LLCI & ULCI \\
\hline Düşük & $-0,298$ & 0,075 & $-3,97$ & $0,001^{* * *}$ & $-0,445$ & $-0,151$ \\
\hline Orta & $-0,413$ & 0,076 & $-5,44$ & $0,000^{* * *}$ & $-0,562$ & $-0,264$ \\
\hline Yüksek & $-0,528$ & 0,083 & $-6,34$ & $0,000^{* * *}$ & $-0,692$ & $-0,364$ \\
\hline
\end{tabular}

$p<0.05^{*}, p<0.01^{* *}, p<0.001^{* * *}$

Elde edilen sonuçlara göre personel güçlendirmenin düşük düzeyi için örgütsel destek algisının $(\beta=-0,298 ; p<0,001 ; \% 95 B G A=$ $[-0,445 ;-0,151])$ işten ayrllma niyetine yönelik negatif yönlü anlamlı bir etkisinin olduğu anlaşılmıştır. Benzer şekilde personel güçlendirmenin orta düzeyi için örgütsel destek algısının $(\beta=-0,413 ; p<0,000$; \%95 BGA = $[-0,562 ;-0,264])$ ve personel güçlendirmenin yüksek düzeyi için örgütsel destek algısının $(\beta=-0,528 ; p<0,000 ; \% 95 B G A=[-0,692 ;-0,364])$ işten ayrılma niyeti üzerindeki anlamlı etkisinin negatif yönde olduğu anlaşılmıştır. Şekil 4'te etkileşimlere ait eğim grafiği gösterilmiştir.

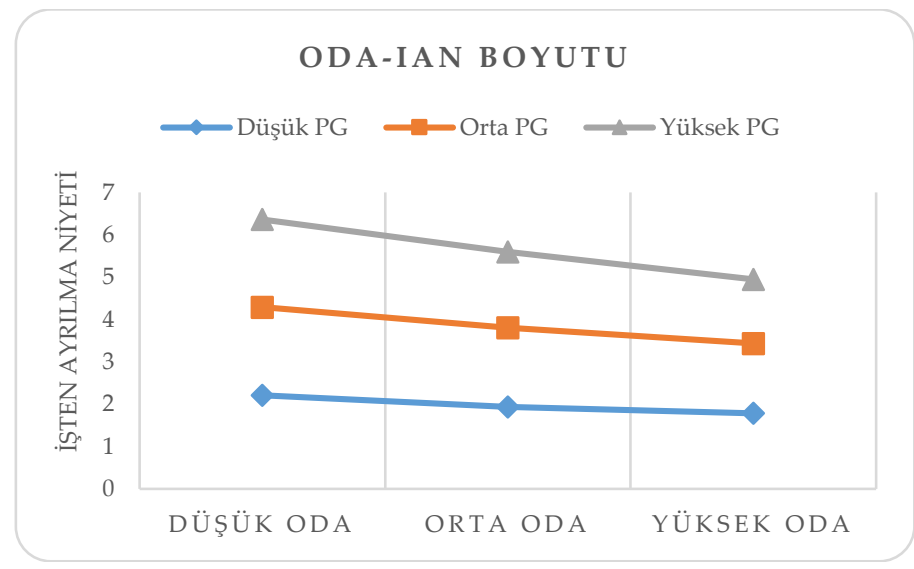

Şekil 4. Farklı PG düzeyleri için ODA'nın IAN'ye etkisi

Şekil 4'te personel güçlendirmenin düşük, orta ve yüksek seviyeleri için çalışanların örgütsel destek algıları arttıkça işten ayrılma niyetinde azalmanın gerçekleştiği görülmektedir. Yüksek personel güçlendirme düzeyinin orta ve 
düşük personel güçlendirme düzeylerine göre doğruların eğimleri karşılaştırıldığında örgüt destek algısının işten ayrılma niyeti üzerindeki etkisinin daha etkili olduğu anlaşılmaktadır.

\section{Sonuç ve Öneriler}

Bu araştırma ile çalışanların iş tatmini ve işten ayrılma niyeti üzerinde önemli etkileri olan örgütsel destek algısının işten ayrılma niyeti üzerindeki etkisinin belirlenmesi ve örgütsel destek algısı ile işten ayrılma niyeti ilişkisinde personel güçlendirmenin rolünün belirlenmesi amaçlanmıştır. Bu anlamda çalışmanın analizinden elde edilen bulgular, personel güçlendirmenin yüksek, orta ve düşük seviyeleri için çalışanların örgütsel destek algılarının artmasıyla işten ayrılma niyetinde azalmanın olduğunu ortaya koymaktadır. Benzer şekilde örgüt destek algısının personel güçlendirmeyi pozitif yönde etkilediği ve örgütsel destek algısının işten ayrılma niyeti etkisinde personel güçlendirmenin aracı etkiye sahip olduğu sonucu ortaya çımıştır. Daha önceki yapılan çalışmaların (Iqbal ve Hashmi, 2015; Akgündüz ve Bardakoğlu 2017) bulguları ile örgütsel destek algısının işten ayrılma niyeti üzerindeki etkisinde personel güçlendirmenin aracı etkisine yönelik çalışmanın bu bulgularını desteklemektedir.

Örgütsel destek, çalışanların iş tatmini ve örgütsel bağlllığını etkilerken işten ayrılma niyetini azaltmaktadır (Wayne vd., 1997; Eisenberger vd., 2001; Rhoades ve Eisenberger 2002). Çalışanların örgütsel destek algısının işten ayrılma niyetini negatif yönde etkilediğine ilişkin daha önceki yapılan çalışmaların (Foong-ming, 2008; Filipova, 2011; Duarte vd., 2015; Kumar, 2015; Liu ve Liu 2015; Saoula ve Johari 2016; DeConinck ve DeConinck 2017) sonuçları çalışmanin bu sonucunu desteklemektedir.

Personel güçlendirme, işyerindeki bireylerin karar verme sürecine katılmalarına ve düşüncelerini özgürce ifade etmelerine katkı sağlayarak işyerindeki bireylerin örgütsel bağlllı̆̆ı ve performansının artmasına ve işten ayrılma niyetinin azalmasına etki etmektedir (İplik vd., 2014; Kim ve Fernandez, 2017; Singh ve Singh, 2019). Daha önce çalışanların personel güçlendirme algısı ile işten ayrılma niyeti arasındaki ilişkiyi konu olan çalışmaların (Bhatnagar, 2012; Lim vd., 2016; Kim ve Fernandez 2017; Hampton ve Rayens 2019; Lyu vd., 2019) bulguları araştırmanın bu bulgusu ile örtüşmektedir. 
Araştırmanın diğer bir bulgusu da çalışanların örgütsel destek algısı ile işten ayrılma niyeti arasındaki ilişkide personel güçlendirmenin düzenleyici rolünün varlığıdır. Alan yazıda çalışanların örgütsel destek algısı ile işten ayrılma niyeti arasındaki ilişkide personel güçlendirmenin düzenleyici etkisinin incelendiği bir araştırmaya rastlanılamadığı için çalışmanın bu sonucunun literatüre katkı sağlayacağı düşünülmektedir. Alan yazıda Manzoor vd., (2016) ve Farzaneh vd., (2014) yapmış oldukları çalışmada personel güçlendirmenin düzenleyici rolünün olduğunu araştırma sonuçlarında ortaya koymuşlardır.

Çalışmanın tekstil sektöründe yapılmış olması araştırmanın önemli bir k1sıtı olup farklı sektörde yapılarak sektörler açısından karşılaştırma yapılması önerilmektedir. Ayrıca başka bir çalışmada farklı değişkenleri kullanarak çalışanların işten ayrılma niyetini etkileyen faktörlerin belirlenmesi mümkündür. Bahsedilen bu kısıtlara rağmen personel güçlendirmenin düzenleyici rolünün etkisinin literatüre ve yöneticilere faydası olacağı beklenmektedir. 


\section{EXTENDED ABSTRACT}

\section{Examining Medaiting and Moderating Role of Personnel Empowerment in the Effect of the Perceived Organizational Support on intention to leave work: Structural Equation Model Application in Textile Sector}

Emre Yakut

Osmaniye Korkut Ata University

Perceived organizational support is defined as individuals' feelings about the extent to which the organization values the works that employee do and cares about their well-being (Eisenberger et al., 1986, p.500; İplik et al., 2014, pg.111; Polatc1, 2015, p.26). Perceived organizational support is the feelings that the employees perceive and affects their behavior against the work place and organization (Erdoğan, 1996, p.2; Taştan et al., 2014, p.122). DeConinck et al. (2015) based the perception of organizational support on social exchange theory, and explained it as the positive or negative response expected by management in response to the activities performed by the employee (Demirer, 2017, p.1046).

Organizational support theory that expresses the perception of the policies carried out by the organization by individuals suggests that when individuals perceive that organizational practices contribute to their usefulness, they may respond with organizational commitment and increased performance (Rhoades and Eisenberger, 2002, p.698; Demircan and Yild1z, 2009, pg.75). Studies found that while the job satisfactions and organizational commitments of employees increase based on their increased work performance since their socio-emotional needs such as approval and respect were fulfilled thanks to perceived organizational support, their intention to quit decreases (Rhoades and Eisenberger, 2002, p.699; Tanrıverdi and Kılıç, 2016, p.6).

Employee empowerment causes the top management in the organizational structure to enable the employee to gain the authority and responsibility, become the owner of the job, have the courage to do the job, gain experience about the job and increase their self-confidence (Gürbüz et al., 2013, 
p.791; Yüksel and Adıgüzel, 2015, p.1020). Thomas and Velthouse (1990) defines employee empowerment practice is among the human resources practices that enable the employee to take action by giving them power and authority (Karavardar, 2017, p.16). Brymer (1991) defines it as the participation of employees in the organizational decision making process and their presentation by the managers (Mete et al., 2015, p.139). From a psychological perspective, Conger and Kanungo (1988) explains employee empowerment as a mood that the employee believes they are capable of performing a task.

The intention to quit which expresses the will of the individual to not work in the work place (Porter et al., 1974) causes individuals to willingly or unwillingly quit their job within a certain time (Mobley, 1982), and the individuals desires it in a planned and conscious way (Tett and Meyer, 1993, Bayarçelik and Findıklı, 2017, p.19; Bayarçelik, 2020, p.38). If the employee who wants to quit their job is qualified and an important employee of the organization, this situation will be a lost for the organization; however, if they are unqualified and inefficient employee of the organization, it will not be considered as a loss (Ar1 et al., 2010, p.146).

This study aims to reveal the mediating and moderating role of employee empowerment in the effect of perceived organizational support of the employees in the textile sector on the intention to quit. Additionally, the study will test whether employee empowerment has an mediating and moderating role on the effect of perceived organizational support on the intention to quit with hypotheses.

The study was conducted with employees in the textile sector in Gaziantep, Turkey. Lisrel 8.7 software and Hasyes' SPSS Process macro were used for the analysis of the covariation-based structural equality model.

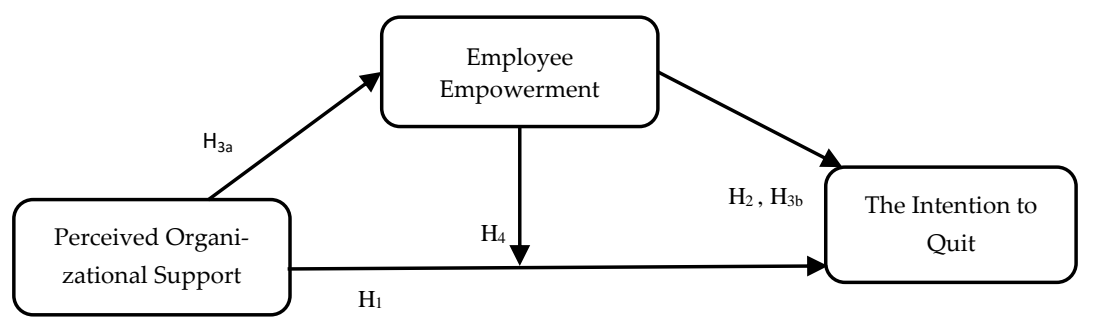

Figure 2. Study Model 
This study which aims to reveal the mediating and moderating role of personnel empowerment on the effect of perceived organizational support on the intention to quit will contribute to the relevant literature. The study also represents one of the limited number of practices on the moderating effect of personnel empowerment on the correlation between perceived organizational support and the intention to quit.

The hypotheses of the model formed with the support of the literature are as follows:

- H1: Perceived organizational support has a negative effect on the intention to quit.

- $\mathbf{H}_{2}$ : Employee empowerment has a negative effect on the intention to quit.

- $\mathbf{H}_{3}$ : Employee empowerment has an mediating role on the effect perceived organizational support on the intention to quit.

- $\mathbf{H}_{4}$ : Employee empowerment has a moderating role on the correlation between perceived organizational support and the intention to quit.

The study revealed that perceived organizational support positively affected employee empowerment, and employee empowerment in the effect of the intention to quit has an mediating effect between perceived organizational support and the intention to quit. The findings of previous studies (Iqbal and Hashmi, 2015; Akgündüz and Bardakoğlu 2017) supports the findings of this study on the mediating effect of employee empowerment on the effect of perceived organizational support on the intention to quit.

Organizational support affects the job satisfaction and organizational commitment of employees, and decreases their intentions to quit (Wayne et al., 1997; Eisenberger et al., 2001; Rhoades and Eisenberger, 2002). Similar to this study, previous studies have reported that perceived organizational supports of employees negatively affects their intentions to quit (Foong-ming, 2008; Filipova, 2011; Duarte et al., 2015; Kumar, 2015; Liu and Liu, 2015; Saoula and Johari, 2016; DeConinck and DeConinck, 2017).

Employee empowerment contributes to the participation of employees to organizational decision-making processes and expression of their opinions freely while increasing the organizational commitment and performance of employees and decreasing their intentions to quit (İplik et al., 2014; Kim and Fernandez, 2017; Singh and Singh, 2019). The findings of previous studies on the correlation between employee empowerment and the intention to quit 
(Bhatnagar, 2012; Lim et al., 2016; Kim and Fernandez, 2017; Hampton and Rayens, 2019; Lyu et al., 2019) support the findings of the current study.

The study also found that employee empowerment has a moderating role on the correlation between perceived organizational support and the intention to quit. This finding of the study will contribute to the relevant literature as there are no studies which examine the moderating role of employee empowerment on the correlation between perceived organizational support of employees and the intention to quit. Manzoor et al. (2016) and Farzaneh et al. (2014) revealed the existence of moderating role of employee empowerment in their study findings.

The fact that the study was conducted in the textile sector is an important limitation. The researchers suggest that more studies should be conducted in different sectors and comparisons should be made. Additionally, another study may determine the factors affecting employees' intentions to quit by using different variables. Although the abovementioned limitations, the moderating role of employee empowerment is expected to be beneficial for the relevant literature and managers.

\section{Kaynakça / References}

Akgunduz, Y., ve Bardakoglu, O. (2017). The impacts of perceived organizational prestige and organization identification on turnover intention: The mediating effect of psychological empowerment. Current Issues in Tourism, 20(14), 1510-1526.

Akkoç, İ., Çalışkan, A., ve Turunç, Ö. (2012). Örgütlerde gelişim kültürü ve alg1lanan örgütsel desteğin iş tatmini ve iş performansına etkisi: Güvenin aracılık rolü. Yönetim ve Ekonomi: Celal Bayar Üniversitesi İktisadi ve İdari Bilimler Fakültesi Dergisi, 19(1), 105-135.

Aksu, G., Eser, M. T., ve Güzeller, C. O. (2017). Açımlayıcı ve doğrulayıcı faktör analizi ile yapısal eşitlik modeli uygulamaları. Ankara: Detay Yayıncilık.

Alpar, R. (2013). Uygulamalı çok değişkenli istatistiksel yöntemler. Ankara: Detay Yayincilik.

Arı, G. S., Bal, H., ve Bal, E. Ç.(2010). İşe bağlılığın tükenmişlik ve işten ayrılma niyeti ilişkisindeki aracllık etkisi: Yatırım uzmanları üzerinde bir araştrrma. Süleyman Demirel Üniversitesi İktisadi ve İdari Bilimler Fakültesi Dergisi, 15(3), 143-166. 
Baron, R. M., ve Kenny, D. A. (1986). The moderator-mediator variable distinction in social psychological research: Conceptual, strategic, and statistical considerations. Journal of personality and social psychology, 51(6), 1173-1182.

Bayarçelik, E. B., ve Fındıklı, M. (2017). İş tatminin, örgütsel adaletin işten ayrılma niyeti ilişkisindeki aracllı rolü. Beykent Üniversitesi Sosyal Bilimler Dergisi, 10(1), 16-31.

Bayarçelik, E.B. (2020). Etik liderliğin işten ayrılma niyeti üzerindeki etkisinde algılanan örgütsel adaletin aracilık rolü. Turkish Studies - Social, 15(2), 3150 .

Beğenirbaş, M., ve Çalışkan, A. (2014). Duygusal emeğin iş performansı ve işten ayrılma niyetine etkisinde kişilerarası çarpıklığın aracilık rolü. Business and Economics Research Journal, 5(2), 109-127.

Beğenirbaş, M., ve Çalışkan, A. (2014). Duygusal emeğin iş performansı ve işten ayrılma niyetine etkisinde kişilerarası çarpıklığın aracılık rolü. Business and Economics Research Journal, 5(2), 109-127.

Bhatnagar, J. (2012). Management of innovation: Role of psychological empowerment, work engagement and turnover intention in the Indian context. The International Journal of Human Resource Management, 23(5), 928951.

Brymer, R. A. (1991). Employee empowerment: A guest-driven leadership strategy. Cornell Hotel and Restaurant Administration Quarterly, 32(1), 58-68.

Cammann, C. (1983). Assessing the attitudes and perceptions of organizational members. Assessing organizational change: A guide to methods, measures, and practices, $71-138$.

Candan, H., Canbolat, M., e Öksüz, Y. (2016). Personel güçlendirmenin örgütsel bağlllık üzerine etkisi: bir kamu kurumunda araştırma. Kahramanmaraş Sütçü İmam Üniversitesi İktisadi ve İdari Bilimler Fakültesi Dergisi, 5(2), 255266.

Conger, J. A., ve Kanungo, R. N. (1988). The empowerment process: Integrating theory and practice. Academy of Management Review, 13, 471-482.

Çavuş, D. M. F. (2008). Personel güçlendirme: imalat sanayi işletmelerinde bir araştirma. Journal of Yaşar University, 3(10), 1287-1300.

Çokluk, Ö. Şekercioğlu, G., ve Büyüköztürk, Ş., (2010). Sosyal bilimler için çok değişkenli istatistik: SPSS ve LISREL uygulamaları. Birinci Baskı. Ankara: Pegem Akademi. 
DeConinck, J., DeConinck, M. B., ve Lockwood, F. (2015). Influence of job fit, perceived support, and organizational identification in the sales force: An analysis of antecedents and outcomes. Archives of Business Research, 3(5). 51-60.

DeConinck, J., ve DeConinck, M. B. (2017). The relationship between servant leadership, perceived organizational support, performance, and turnover among business to business salespeople. Archives of Business Research, 5(10).57-71.

Demircan Ç. N., ve Yildiz, S. (2009). Örgütsel adaletin is tatmini üzerindeki etkisi:" Algilanan örgütsel destek" bir ara değişken mi?. Electronic Journal of Social Sciences, 8(28), 68-90.

Demirer, M. C. (2017). Örgütlerde destek algılarının çalışanın duygularını ifade etmesi üzerine etkisi. Hitit Üniversitesi Sosyal Bilimler Enstitüsü Dergisi, 10(2), 1043-1060.

Duarte, A. P., Gomes, D., ve Neves, J. (2015). Satisfaction with human resource management practices and turnover intention in a five-star hotel: The mediating role of perceived organizational support. Satisfaction with human resource management practices and turnover intention in a five-star hotel: the mediating role of perceived organizational support, A Multidisciplinary E-journal, 25, 103-123.

Eisenberger, R., Armeli, S., Rexwinkel, B., Lynch, P. D., ve Rhoades, L. (2001). Reciprocation of perceived organizational support. Journal of applied psycho$\log y, 86(1), 42-51$.

Eisenberger, R., Huntington, R., Hutchison, S., ve Sowa, D. (1986). Perceived organizational support. Journal of Applied psychology, 71(3), 500-507.

Erdoğan, İ. (1996). İşletme yönetiminde örgütsel davranış. İstanbul:İşletme Fakültesi Yayını.

Eskibina, Y. (2019). Personel güçlendirmenin iş tatminine etkisi: Yardımcı yarg1 personeli üzerine bir araştırma. Electronic Journal of Social Sciences, 18(72).1609-1618.

Farzaneh, J., Farashah, A. D., ve Kazemi, M. (2014). The impact of person-job fit and person-organization fit on OCB. Personnel Review, 43(5), 672-691.

Filipova, A. A. (2011). Relationships among ethical climates, perceived organizational support, and intent-to-leave for licensed nurses in skilled nursing facilities. Journal of Applied Gerontology, 30(1), 44-66. 
Foong-ming, T. (2008). Linking Career development practices to turnover intention: The mediator of perceived organizational support. Journal of Business and Public Affairs, 2(1), 1-16.

Gagne, M., ve Deci, E. L. (2005). Self-determination theory and work motivation. Journal of Organizational behavior, 26(4), 331-362.

Gürbüz, G., Kumkale, İ., ve Oğuzhan, A. (2013, September). Bankacilık sektöründe personel güçlendirme uygulamalarının örgütsel bağlılığa etkisi: Trakya Bölgesi bankalarında araştırma. In International Conference On Eurasian Economies (Vol. 2, p. 791-800).

Gürbüz, S., ve Bekmezci, M. (2012). İnsan kaynakları yönetimi uygulamalarının bilgi iş̧̧ilerinin işten ayrılma niyetine etkisinde duygusal bağllı̆̆ı̆ aracllık ve düzenleyicilik rolü. İstanbul Üniversitesi İsletme Fakültesi Dergisi, 41(2), 189-213.

Hampton, D., ve Rayens, M. K. (2019). Impact of psychological empowerment on workplace bullying and intent to leave. JONA: The Journal of Nursing Administration, 49(4), 179-185.

Iqbal, S., ve Hashmi, M. S. (2015). Impact of perceived organizational support on employee retention with mediating role of psychological empowerment. Pakistan Journal of Commerce and Social Sciences (PJCSS), 9(1), 18-34.

İplik, E., İplik, F. N., ve Efeoğlu, İ. E. (2014). Çalişanlarin örgütsel destek algilarinin örgütsel vatandaşlik davranişi üzerindeki etkisinde örgütsel öz-deşleşmenin rolü. 1. Uluslararası İktisadi ve İdari İncelemeler Dergisi, 12.

İplik, E., Tuğal, F. N., ve Efeoğlu, İ. E. (2014). Çalışanların örgütsel destek algilarının örgütsel vatandaşlık davranışı üzerindeki etkisinde örgütsel özdeşleşmenin rolü. Uluslararası İktisadi ve İdari İncelemeler Dergisi, 6(12), 109122.

İplik, E., Tuğal, F. N., ve Efeoğlu, İ. E. (2014). Çalışanların örgütsel destek algılarının örgütsel vatandaşlık davranışı üzerindeki etkisinde örgütsel özdeşleşmenin rolü. Uluslararası İktisadi ve İdari İncelemeler Dergisi, 6(12), 109122.

Kanbur, E. (2018). Havacilık sektöründe psikolojik güçlendirme, iş performansı ve işten ayrılma niyeti arasındaki ilişkilerin incelenmesi. Uluslararası Yönetim İktisat ve İsletme Dergisi, 14(1), 147-162.

Karavardar, G. (2017). Mavi yakalı çalışanlarda psikolojik personel güçlendirme ve iş tatmini arasındaki ilişkileri belirlemeye yönelik görgül bir araştrrma. Osmaniye Korkut Ata Üniversitesi İktisadi Ve İdari Bilimler Fakültesi Dergisi, 1(1), 15-26. 
Kaymaz, K., Eroğlu,U., ve Sayılar, Y. (2014). Effect of loneliness at work on the employees' intention to leave. ISGUC the Journal of Industrial Relations and Human Resources, 16(1), 38-53.

Kim, S. Y., ve Fernandez, S. (2017). Employee empowerment and turnover intention in the US Federal Bureaucracy. The American Review Of Public Administration, 47(1), 4-22.

Kitapc1, H., Kaynak, R., ve Okten, S. (2013). Güçlendirmenin iş tatmini ve işten ayrilma niyetine etkisi: kamu ve özel sektörde mukayeseli bir araştirma. International Review of Economics and Management, 1(1), 49-73.

Knapp, J. R., Smith, B. R., ve Sprinkle, T. A. (2017). Is it the job or the support? examining structural and relational predictors of job satisfaction and turnover intention for nonprofit employees. Nonprofit And Voluntary Sector Quarterly, 46(3), 652-671.

Kumar, N. (2015). Role of perceived organizational support and justice on employee turnover intentions: Employee engagementas mediator. International Journal of Management and Applied, 1(3), 50-59.

Lim, Y. J., Osman, A., Abdul Manaf, A. H., ve Abdullah, S. M. (2016). Antecedents and outcome to quit: evidence from financial institution bank employees. Specialty Journal of Accounting and Economics, 2(1), 19, 29.

Liu, J., ve Liu, Y. H. (2016). Perceived organizational support and intention to remain: The mediating roles of career success and self-esteem. International journal of nursing practice, 22(2), 205-214.

Lyu, D., Ji, L., Zheng, Q., Yu, B., ve Fan, Y. (2019). Abusive supervision and turnover intention: Mediating effects of psychological empowerment of nurses. International Journal of Nursing Sciences, 6(2), 198-203.

Manzoor, F., Sadozai, K. N., ve Jan, D. (2016). Evaluating the role of human Resource management (HRM) practices on job performance: An application of employee empowerment as moderator. City University Research Journal, 6(2), 354-363.

Mete, M., Zincirkıran, M., Yalçınsoy, A., ve Pekcan, A. (2015). Personel güçlendirme, örgütsel bağlllık ve iş memnuniyeti ilişkisinin yapısal eşitlik modeli ile incelenmesi: Turizm sektöründe bir araştırma. Bartın Üniversitesi İ̈BF Dergisi, 6(12), 137-156.

Mobley, W. H. (1982). Some unanswered questions in turnover and withdrawal research. Academy of management review, 7(1), 111-116. 
Naktiyok, A., ve Kızıl, S. (2018). Örgütsel destek ve özyeterlik algısının akademik erteleme davranışı üzerine etkisi: Araştırma görevlileri üzerinde bir inceleme. İşletme Araştırmaları Dergisi, 10(4), 267-285.

Onay, M., ve Kılcı, S. (2011). İş stresi ve tükenmişlik duygusunun işten ayrılma niyeti üzerine etkileri: Garsonlar ve aşçbaşılar. Organizasyon ve Yönetim Bilimleri Dergisi, 3(2), 363-372.

Polatc1, S. (2015). Örgütsel ve sosyal destek algılarının yaşam tatmini üzerindeki etkisi: İş ve evlilik tatmininin aracılık rolü. Ekonomik ve Sosyal Araştırmalar Dergisi, 11(2), 25-44.

Porter, L. W., Steers, R. M., Mowday, R. T., ve Boulian, P. V. (1974). Organizational commitment, job satisfaction, and turnover among psychiatric technicians. Journal of applied psychology, 59(5), 603-609.

Rhoades, L., \& Eisenberger, R. (2002). Perceived organizational support: a review of the literature. Journal of applied psychology, 87(4), 698-714.

Saoula, O., ve Johari, H. (2016). The mediating effect of organizational citizenship behaviour on the relationship between perceived organizational support and turnover intention: a proposed framework. International Review of Management and Marketing, 6(7S), 345-354.

Singh, S. K., ve Singh, A. P. (2019). Interplay of organizational justice, psychological empowerment, organizational citizenship behavior, and job satisfaction in the context of circular economy. Management decision. Sociological Review, 25(2), 161-178.

Spreitzer, G., M., De Janasz, S. C. ve Quinn, R.E. (1999). Empowered to lead: The role of psychological empowerment in leadership. Journal of Organizational Behavior, 20(4), 511-526.

Spreitzer, G.M. (1995). Psychological empowerment in the workplace: Construct definition, measurement, and validation. Academy of Management Journal, 38(5), 1442-1465.

Spreitzer, G.M., Kizılos, M. A. ve Nason, S.W. (1997). A dimensional analysis of the relationship between psychological empowerment and effectiveness, satisfaction, and strain. Journal of Management, 23(5), 679-704

Tanrıverdi, H., ve Kılıç, N. (2016). Algılanan örgütsel destek ve örgütsel yabanc1laşma arasındaki ilişkinin incelenmesi. Hacettepe Üniversitesi, Sosyolojik Araştırmalar E-Dergisi, 1(1), 1-18. 
Taştan, S., İşçi, E., ve Arslan, B. (2014). Örgütsel destek algisinin işe yabancilaşma ve örgütsel bağliliğa etkisinin incelenmesi: İstanbul özel hastanelerinde bir çalişma. Pamukkale Üniversitesi Sosyal Bilimler Enstitüsü Dergisi, 19, 121-138.

Tett, R. P., ve Meyer, J. P. (1993). Job satisfaction, organizational commitment, turnover intention, and turnover: path analyses based on meta-analytic findings. Personnel psychology, 46(2), 259-293.

Thomas, K. W., ve Velthouse, B. A. (1990). Cognitive elements of empowerment: An "interpretive" model of intrinsic task motivation. Academy of management review, 15(4), 666-681.

Wayne, S. J., Shore, L. M., ve Liden, R. C. (1997). Perceived organizational support and leader-member exchange: A social exchange perspective. Academy of Management journal, 40(1), 82-111.

Yılmaz, H., ve Görmüş, A. Ş. (2012). Stratejik girişimciliğin, algılanan örgütsel destek ve örgütsel öğrenme üzerine etkilerinin araştırılması: Tekstil sektöründe ampirik bir çalışma. Journal of Yasar University, 7(26), 4483-4504.

Yılmaz, H., ve Karahan, A. (2015). Yüksek performanslı insan kaynakları yönetimi uygulamaları, psikolojik güçlendirme ve duygusal bağlılık arasındaki ilişkilerin incelenmesi: Tekstil sektöründe bir araştırma. Dokuz Eylül Üniversitesi Sosyal Bilimler Enstitüsü Dergisi, 16(4), 607-637.

Yılmaz, Ö., ve Eroğluer, K. (2018). Turizm sektöründe personel güçlendirme ve güç mesafesinin işten ayrılma niyeti üzerindeki etkisi: Bir uygulama. Global Journal of Economics and Business Studies, 7(13), 65-81.

Yüksel, O., ve Adıgüzel, O. (2015). Kamu hastaneleri birliği kapsamında yer alan sağlık kurumlarında çalışanlar açısından personel güçlendirmenin iş tatmini ve iş motivasyonu üzerine etkilerinin çeşitli değişkenlere göre incelenmesi. Journal Of International Social Research, 8(39), 1019-1027.

Yürür, S. ve Ünlü, O. (2011). Duygusal emek, duygusal tükenme ve işten ayrılma niyeti ilişkisi. ISGUC The Journal of Industrial Relations and Human Resources, 13(2), 81-104. 


\section{Kaynakça Bilgisi / Citation Information}

Yüksel, İ. (2020). Örgütsel destek algısının işten ayrılma niyeti etkisinde personel güçlendirmenin aracı ve düzenleyici rolü: Tekstil sektöründe yapısal eşitlik modeli uygulaması. OPUS-Uluslararası Toplum Araştırmaları Dergisi, 15(26), 4070-4100. DOI: 10.26466/opus.738785 